\title{
On the Behaviour during Drought of Leaves of two Cape Species of Passerina, with some Notes on their Anatomy.
}

\author{
BY \\ D. THODAY, M.A. (Cantab.), \\ Harry Bolus Professor of Botany in the University of Cape Town.
}

With thirteen Figures in the Text.

NE of the features of the vegetation of the Cape Peninsula which immediately strikes the observer is the prevalence of shrubby plants with small, often narrow leaves. Closer observation shows that many of these have leaves of a strictly ericoid type, with grooves usually more or less filled with hairs, the stomata being confined to the epidermis lining the groove. These plants belong to various families. Of the numerous species of Erica and other genera of Ericaceae, all but a few possess leaves of this type. They are found also in Stilbe ericoides and S. vestita (Verbenaceae), Phylica spp. (Rhamnaceae), Rhus rosmarinifolia (Anacardiaceae), Passerina filiformis and Chymococca empetroides (Thymelaeaceae), Grubbia rosmarinifolic (Grubbiaceae), and in several genera of Compositae, including Stoebe, Disparago, Elytropappus, and Metalasia. This list is by no means exhaustive.

A fact of some interest with regard to a number of the species was communicated to the South African Association for the Advancement of Science at the meeting in Bulawayo in July, I920, namely, that the grooves vary in the width of their opening with changes in the conditions. In the dry summer of 1920 , in February and March, the leaves of Erica spp., Stilbe vestita, and Passerina filiformis were found with the grooves quite or nearly closed on plants in specially dry situations.

In Passerina the closure of the grooves was observed more frequently than in the other species. This was therefore selected first for detailed study.

Passerina filiformis is widely distributed in South Africa. In the Cape Peninsula it is very common, extending from a little above sea-level to at least a thousand feet on the mountain slopes. ${ }^{1}$

1 Bolus and Wolley-Dod: Flowering Plants and Ferns of the Cape Peninsula. Trans. S. African Phil. Soc., xiv, I903, p. 3'5.

[Annals of Botany, Vo1. XXXV. No. CXL. October, I921.] 
Observations in the field, made subsequently to much of the experimental work described in this paper, make it clear that two forms are to be distinguished among the plants that had been used, one of which is almost certainly Passerina filiformis, Linn.; the other resembles $P$. falcifolia, C. H. Wright, though it does not agree in all respects with Wright's description in the 'Flora Capensis'.1

The former commonly reaches a height of four or five feet. It has numerous erect branches and more or less adpressed leaves, decussately arranged and, when young, closely adpressed to one another in four conspicuous ranks.

The other form has a more spreading, bushy habit; the leaves are longer, and are not adpressed except when young, but spread at an angle of $45^{\circ}$ or more from the stem.

In much-shaded situations, plants belonging to the latter form are found with a very lax habit, with leaves spreading still more widely and branches slender and straggling.

In both forms the leaf is grooved on the upper side, the groove being thickly lined with close, woolly hairs. When the leaves are adpressed the groove is brought near to the surface of the stem, which is pubescent when young.

In herbarium material the leaf-grooves are tightly closed so that the leaves appear acicular.

\section{Closure of the Groove and Water Content.}

In the dry season (from January to March) the grooves are narrowed by the approximation of the two sides of the leaves, until the edges may meet over the groove and completely enclose it. Closure proceeds from the tip towards the base, where communication with the outer air is maintained except in extreme drought.

The following experiment shows how closure is correlated with diminishing water content :

A shoot was brought to the laboratory in the latter part of February, 1920 , and kept in a full vasculum, weighed the following day, and then put with the cut end of the stem in water under a bell-jar. Most of the leaves had their grooves tightly closed. By the next day they had opened well. After another day the shoot was finally weighed and its dry weight determined. The results are given in Table I.

$1 P$. falcifolia is described as having the bracts densely woolly within. In my specimens there is only a narrow band of woolly hairs, continuous with the groove of the narrow leaf-like apex, while the wings are glabrous. No record of $P$. falcifolia from the Cape Peninsula is mentioned in Flora Capensis, and Bolus and Wolley-Dod (loc. cit.) did not separate the form in question from $P$. filiformis. The leaf characters, however, are more like those of $P$. falcifolia and distinguish it from all the other species described. 


\section{Cape Species of Passerina, with some Notes on their Anatomy. 587}

TABLE I.

Original weight, grooves closed

After 6 hours, grooves mostly still closed

Weight
in grm.
6.81
7.50
9.05
9.23
4.87

Water Content. $\%$ of fresh weight. $\%$ of dry weight.

After 22 hours, grooves open

After 48 hours, grooves open Dry weight

$28 \cdot 6$
$35 \cdot 0$
$46 \cdot 2$
$47 \cdot 2$
-

40

54

86

89

The water content of the shoot as gathered was thus surprisingly low. The experiment showed nevertheless that the shoot was fully able to recover its turgor and the leaves to open their grooves. Even the maximum water content of the turgid shoot was no more than $47 \cdot 2$ per cent.

\section{Range of Water Content in the Dry Season.}

Following on this experiment the fresh weights were determined of a large number of shoots, with precautions against loss of moisture in the interval between collecting and weighing (March 6, 1920); the condition of the leaves was noted and their dry weights found. The shoots were taken from bushes in a variety of situations, probably also of both forms, which at the time I had not realized as specific. In the driest places many of the plants were yellowish or brownish in colour, the insolated sides of twigs and even of individual leaves contrasting markedly with the opposite sides, which were still more or less green.

The shoots were separated into three groups according as the leafgrooves were open, closed, or open in older leaves and closed in younger except at the base. The range of water content in each group is given in the following table:

\section{TABLE II.}

Grooves open

Some grooves open, some closed

Grooves closed

Range of Water Content.
$\%$ of fresh weight. $\%$ of dry weight.
$\begin{array}{cc}45 \cdot 3-37 \cdot 1 & 83-59 \\ 34 \cdot 5-33 \cdot 3 & 53-50 \\ 34 \cdot 1-25 \cdot 7 & 52-35\end{array}$

These figures and those in Table I show that at this season of the year the critical water content at which the grooves closed completely was about 34 per cent. The water content could, however, sink farther to 26 per cent. (about a third of the dry weight) apparently without permanent injury resulting.

This very low water content in still living vegetative shoots appears to be without recorded parallel.

Cases are of course known of plants which become practically air-dry without injury. A very interesting example of such a plant (Myrothammus fabellifolia) grows in cracks on exposed granite slopes in Rhodesia. In the dry season the leaves become plicately folded and tightly adpressed to one another at the tips of the twigs, while these in their turn curve inwards. When the rains come, leaves and branches expand again. 
In July, I920, I collected small twigs of this plant on the Matoppo Hills, near Bulawayo, in the dry folded condition, enclosed them in a corked tube, and on my return to Cape Town a fortnight later found the water content to be only about 7 per cent. Such plants as this must be completely air-dry and dormant.

Passerina, on the other hand, still transpires slowly and is not dormant, however sluggish its vitality may become under such extreme conditions. Determinations of the water content of other plants show that, although the minimum is so far lowest in the case of Passerina, the shoots of not a few sclerophyllous plants may have a water content falling considerably

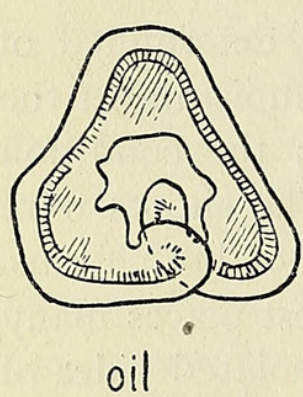

tenth mms.

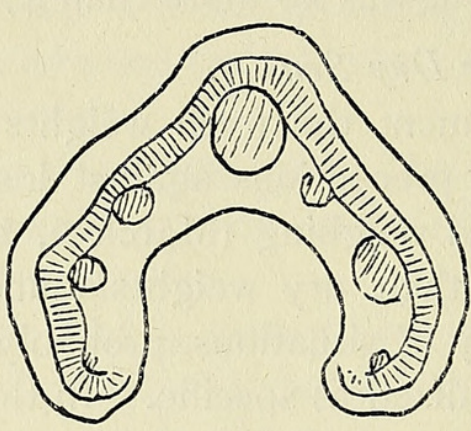

water below 50 per cent. in the summer.

As might be expected, a higher percentage of water is found at other seasons of the year. Shoots of Passerina collected in mid.September, 1920 , had a water content of 59-6I per cent. Even this figure is lower than might have been anticipated in shoots which were collected after rainy weather, towards the end of a wet winter, early

FIG. I. Tracings of adjacent sections from a leaf of Passerina cf. falcifolia in which the groove was tightly closed; left, in oil, the edges overlapping; right, in water, groove open, tissues expanded.

on a cloudy morning. After the first week of summer weather, with a fairly strong dry south-east wind and brilliant sunshine, the water content of shoots of both species, collected in the afternoon, was $5^{6}$ per cent.

\section{Mechanism of Closure.}

When a transverse section of a closed leaf is put into water, it expands at once and the groove opens widely. In order to estimate the degree of expansion involved, adjacent sections cut dry were mounted, one in oil, the other in water, and camera lucida outlines compared.

Cases were often observed of thin sections, either dry or mounted in oil, having their edges overlapping, showing that in the intact leaf the edges were pressed together under tension (Fig. I).

On comparing the sections the change of dimensions proved very considerable. It was most apparent in the mesophyll, where in the closed condition the palisade tissue was so condensed that the individual cells were often difficult to distinguish, while the spongy tissue was relatively still more contracted in volume. The cells of the outer epidermis were also contracted in height. 
The outer epidermis is provided with a very thick cuticle. The inrolling or opening of the leaf is therefore to be attributed to changes of volume taking place within this resistant cuticle. But it is a question of some importance whether changes of turgor are wholly responsible, or, if not, what other forces bring about the movement.

Figs. 2 and 3 illustrate the chief structural details involved. The two sections represented in Fig. 2 are from old healthy leaves from $(a)$ an ordinary sturdy plant of Passerina filiformis with more or less adpressed leaves, $(b)$ an extreme shade plant of Passerina sp.cf. falcifolia, with widely, spreading leaves. The two are in most respects very similar. The most conspicuous difference is in the main bundles, the fibres in $(\alpha)$ interrupting the palisade tissue and reaching the epidermis. This difference appears to be specific ; the continuous palisade of $(b)$ is characteristic of the form with

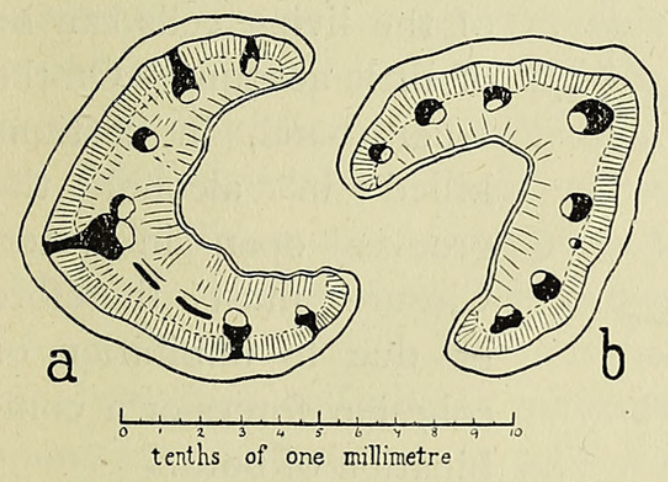

FIG. 2. Diagrams of sections of old healthy leaves of $(a) P$. filiformis, $(b)$ extreme shade plant of $P . c f$. falcifolia. Fibres black; arrangement of mesophyll cells in. dicated by the shading.

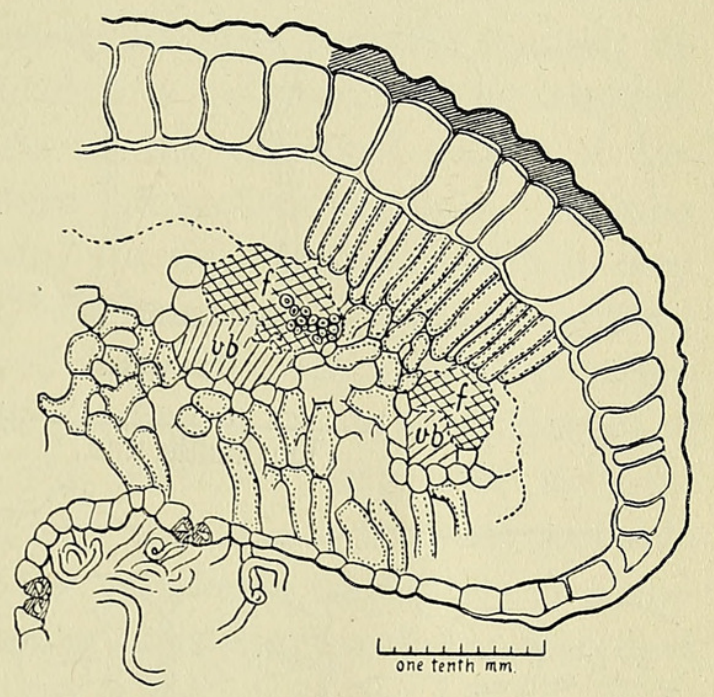

FIG. 3. Part of section of leaf of P.cf. falcifolia. Cuticle of outer epidermis strongly shaded, also the raised guard cells ; $f$, fibres; $v b$, vascular bundles.

spreading habit. It is shown also in Fig. 3, which is from a plant of this form growing in the open.

In this figure the structure is shown more in detail. The outer epidermis is of relatively large cells, deeper than wide. The whole of the shaded part of the outer wall is strongly cutinized. The inner epidermis is thin, clothed with curly hairs, and has numerous raised stomata.

To return to the question of mechanism; experiments were made with sections transferred from water to Io per cent. sodium chloride solution (causing plasmolysis), chloroform water, formalin, and other killing reagents. Plasmolysis was accompanied by only a small narrowing of the groove. Killing with formalin or chromacetic gave a negative or very slight result. With chloroform water the result varied, and this was traced to the direct effect of absorption of chloroform by the cuticle. A section 
mounted on a cover-slip over a cell containing chloroform rapidly closed, but opened again when remounted in fresh water practically as widely as before. Careful measurement showed that the surface of the cuticle increased in length over chloroform vapour. In the particular section measured the increase was $2 \cdot 3$ per cent. Comparison of tracings from a section of a closed leaf, $(a)$ in absolute alcohol and $(b)$ after opening in water, showed no appreciable change in circumference. With chloroform, then, an increase in circumference is responsible for closure; whereas normally closure is due to the contraction of the tissues within the cuticle.

These experiments indicate that the normal position of the cuticle and water-imbibed cell-walls corresponds to the open groove, and that but little

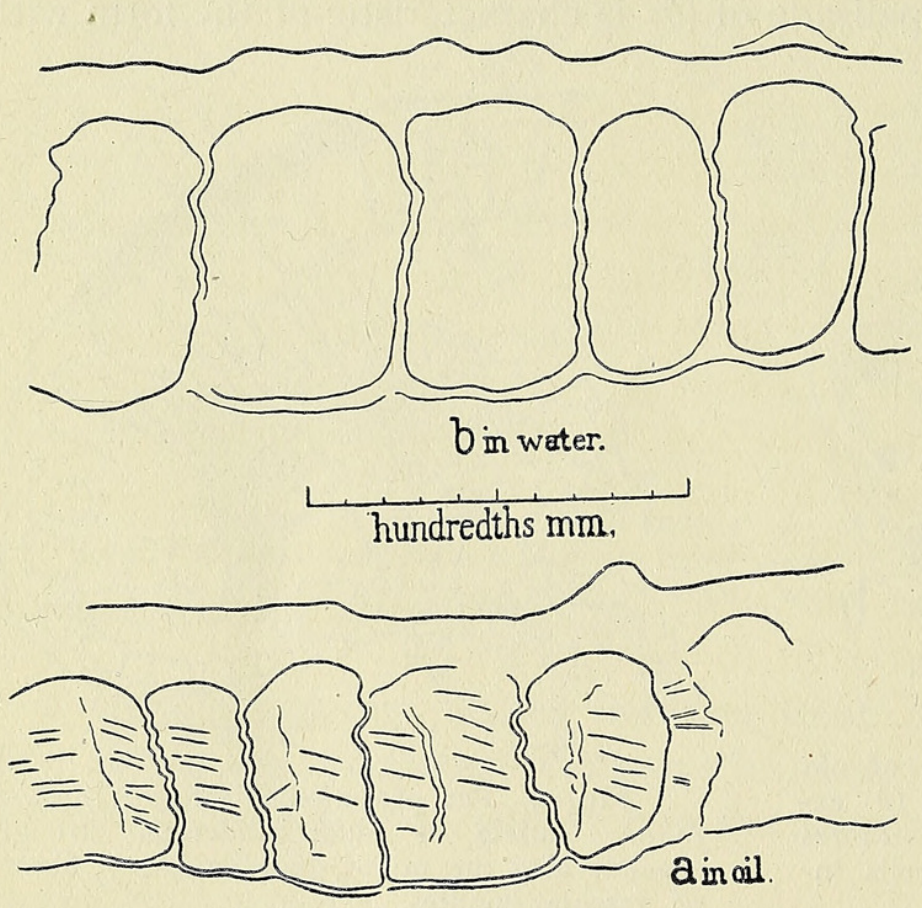

FIG. 4. Epidermis of corresponding parts of two adjacent sections; $(a)$ in oil, showing bellows-like foldings; $(b)$ expanded in water. further opening results from turgor. Any increased opening in short spells of moist weather due to osmotic expansion of the living cells can be of little account. On the other hand, in sections killed in alcohol the grooves open in water. Closure must therefore be due to imbibition or cohesion forces or a combination of both.

In considering the exact location of these forces the thin inner epidermis and loose spongy mesophyll may at once be dismissed; so, too, may the bundles (but see below as regards the fibres in $P$. filiformis, p. 597). The palisade tissue and outer epidermis both contract radially. It is, however, a tangential force which is required, and this, by its structure, the palisade parenchyma is hardly adapted to develop. Moreover, in extreme cases the palisade cells have the appearance of being pressed closely together. The epidermis alone has the tangential continuity necessary to bend the resistant cuticle by its contraction.

Cohesion. That cohesion forces are developed in the outer epidermis of the closing leaf is shown by the lateral folding of the walls. Figs. $4 a$ and $b$ are from camera lucida drawings of cells from corresponding parts of adjacent sections cut dry, one mounted in oil, the other in water. The 
bellows-like folding of the walls is clearly shown in $a$; in $b$ the cells have increased considerably in volume and the walls are nearly straightened. This feature is characteristic of certain kinds of water-storing tissue, a point which will be considered again later. In the present connexion it is a clear indication of cohesion tension drawing the walls together, a tension which must act tangentially as well as at right angles to the surface.

As the epidermis is curved in the expanded condition, the approximation of the short inner to the longer outer walls during the contraction, which is facilitated by the folding of the lateral walls, will in itself bring about an increase in curvature. This effect will be more pronounced where the initial curvature is greater, and in fact it is in such regions that the increase of curvature chiefly occurs (cf. Fig. I). Cohesion therefore acts in two ways to close the groove, by drawing the lateral walls together and by drawing the inner walls to the outer.

Subsidiary factors. The sap of the epidermal cells contains a substance in solution which forms in absolute alcohol a gelatinous mass slightly contracted away from the cell-wall. As to the chemical nature of the substance I have not yet been able to obtain satisfactory evidence. So long as the sap is fluid or semi-fluid it can hardly assist closure, though it may help the cells to resist the loss of water, and may also account in part for the rapid expansion of sections transferred from absolute alcohol to water. In dead cells, such as often occur in small patches in the outer epidermis of old leaves, the contents are brown and the outer wall depressed inwards. The contraction of the lumen is, however, only partial, and it seems probable that complete collapse is prevented by the gelatinous contents. A corresponding phenomenon in cells with mucilaginous inner walls is described below (p. 599).

Associated with the development of cohesion tension in the epidermal cells there will also be a contraction of the inner cellulose wall, which must lose some of its imbibed water in the maintenance of equilibrium between the imbibition and cohesion forces. This contraction would tend to bring about closure of the groove. In the expanded condition these walls bulge inwards somewhat into the palisade tissue; in the contracted condition they are sometimes nearly straight. This straightening, partly due no doubt to the contraction of the walls themselves, partly to the cohesive pull of the contracting contents, involves some deformation of the palisade layer. Any resistance offered to this deformation would assist closure. On the other hand, I have seen cases in which the inner walls were straighter in the expanded condition.

On the whole it seems clear that cohesive forces acting in the outer epidermis play the principal part in the closing mechanism. Other factors may also be concerned in variable degree, but their effects are subsidiary. 


\section{Water Storage, or Absorbing Power?}

Although folding of the walls is easily observed in the epidermal cells it is not confined to them. The cells of the palisade parenchyma in tightly closed leaves may also show fine foldings which are less easily demonstrated. Fig. 5 is from a microtome section of a closed.leaf, fixed in absolute alcohol and carefully embedded in paraffin.

Solereder ${ }^{1}$ mentions the common occurrence of similar foldings in the palisade parenchyma in herbarium material of various plants, and infers that this tissue has water storage as a subsidiary function. To adopt such a suggestion in the present instance would, however, be to overlook the real significance of the phenomenon; for the amount of water that can be stored, even in the epidermis, is small. Moreover, the contracted condition may of necessity persist for a considerable time. True water-storage tissue

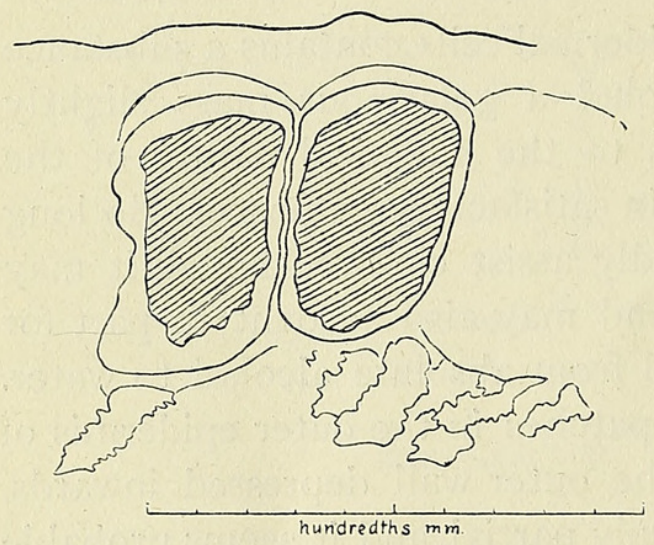

FIG. 5. Outer epidermal and palisade cells from microtome sections of closed leaf, fixed in absoltte alcohol and embedded in paraffin. The contents of each epidermal cell (shaded) form a somewhat contracted brown gelatinous mass. Palisade cells with finely-folded walls. may act either as a reservoir of water on which the active tissues of the organ itself may draw during temporary shortage, so that they may remain actively functioning, or as a reservoir which may be tapped by younger parts of the plant, the older parts yielding up their water and dying. Among succulents both alternatives are represented, often in the same plant. In Passerina the former alternative may apply to a limited extent, in so far as the epidermis yields water to the assimilating tissues. It can, however, only be of service in relation to temporary drought.

As regards the assimilating tissues themselves, the folding of the walls is an accommodation to a greatly diminished water content which may persist sometimes for many weeks. As the cell sap shrinks in volume the cell contracts in length rather than in breadth; it may perhaps be due in part to this regular and structurally determined mode of contraction that the cell survives. The principal fact is, however, the great diminution in volume, to which the cell-wall offers little resistance. There is no hydrostatic pressure in the contracted cell, but the full osmotic pressure of the sap is brought into play for the absorption and retention of water. ${ }^{2}$

The difficulty of detecting the foldings in the palisade cells has prevented extensive comparative observations of the behaviour in this respect of the epidermis and palisade layer. In spring, at any rate, folding

1 Systematic Anatomy of Dicotyledons, vol. ii, p. I088.

2 Cf. Thoday, New Phyt., xvii, I9r8, pp. Io8-I3. 
appears to begin much sooner in the epidermis. In leaves of $P$. cf. falcifolia, after partial drying in the laboratory, the epidermis showed beautifully regular foldings, while no folding could be detected in the palisade cells. On the other hand, Fig. 5 illustrates a case in which the folding was more marked in the palisade cells; this was summer material. Differences of age may perhaps be concerned here, e.g. the walls may be more flexible and extensible in young palisade cells.

However this may be, a considerable change of volume is apparent also in the palisade tissue, even when the epidermis alone shows well-marked folding.

The most reliable data are those obtained with sections mounted in absolute alcohol and afterwards transferred to water, as thinner sections can be cut with a razor moistened with absolute alcohol and the optical conditions are more favourable. In the case of a widely opening leaf of $P$.cf. falcifolia the following. were the averages of numerous radial measurements of a section treated in this way:

\begin{tabular}{|c|c|c|c|}
\hline - & In Water. & $\begin{array}{c}\text { In Absolute } \\
\text { Alcohol. }\end{array}$ & \\
\hline Epidermis, outer wall & $\begin{array}{l}\mu . \\
23\end{array}$ & $\begin{array}{l}\mu . \\
23\end{array}$ & $\%$ \\
\hline pidermis, lumen and inner wall & 72 & 46 & $3^{6}$ \\
\hline Palisade layer & $5^{2}$ & $3^{6}$ & 32 \\
\hline spongy tissue & I97 & 107 & $4^{6}$ \\
\hline
\end{tabular}

Here, of course, the expansion is that of the tissue killed in absolute alcohol, and does not necessarily correspond with what would have occurred had they been still living. Rough measurement of sections measured dry and in water, and comparison of adjacent sections in oil and water, supported these data in a general way; but in some cases the expansion of the palisade tissue of dry sections was proportionately greater than that of the epidermis.

In view of these observations, I am inclined to regard water storage as a function of subsidiary importance even in the epidermis. The properties of the tissues will allow of some expansion during the night, when transpiration is minimal. But it is the increased power of holding and absorbing water which is of prime importance; for cut shoots, even in the laboratory in shade, when deprived of any water-supply, become nearly air-dry in two or three days in the dry season.

Significance of the large-celled Outer Epidermis.

If water storage is only of subsidiary importance, the question of the significance of the thickness of the outer epidermis still remains. Relative to the size of the leaf the cells are very large. They are also large compared with those of many larger leaves. The following table gives the height of the epidermal cells in a few instances, and in some cases the thickness of the outer wall : 


\begin{tabular}{lrc}
\multicolumn{1}{c}{ Plant. } & $\begin{array}{c}\text { Epidermis. } \\
\mu .\end{array}$ & $\begin{array}{c}\text { Outer Wall. } \\
\mu .\end{array}$ \\
Passerina filiformis & $60-95$ & Up to 23 \\
Stilbe vestitalcifolia & $60-100$ & - \\
Protea lepidocarpodendron & 80 & 30 \\
Lobostemon sp. & 30 & - \\
Ivy & 20 & 9 \\
Helianthus (? anmuus) & $10-20$ & -
\end{tabular}

Stilbe vestita, like Passerina, has ericoid leaves. Protea lepidocarpodendron has large, thick and tough, lanceolate leaves. Lobostemon (Boraginaceae) has thick and rather fleshy, coarsely hairy leaves. All these are evergreen plants of the Cape Peninsula maquis. In the first three the thickness of the epidermis is of the same order. They may all be described as sclerophyllous, the leaves being tough. The toughness is largely due to the thick outer wall and cuticle, so that thick outer wall and thick epidermis are correlated in these instances. The data are too few, however, for generalization, and show the need for extensive comparative observations.

Marloth, from long and extensive acquaintance with the Cape flora, has emphasized the view that protection from intense insolation is of great importance in this climate. ${ }^{1} \mathrm{He}$ points to the large number of leaves which assume the vertical position, and suggests that the screening effect of white hairy coverings in other leaves may be as important as the protection they afford against drying winds.

A large-celled epidermis ${ }^{\circ}$ will act as a screen to an extent which must vary as the height of the cells and perhaps also depend upon the nature of the sap. On the latter point research is required. It is of interest, in this connexion, that solutions of tyrosine have been shown to absorb ultra-violet radiation and so reduce the toxicity of light to bacteria and Paramoecium, ${ }^{2}$ and it is not improbable that other substances commonly occurring in plants may be found to have a similar action.

In Passerina, the height of the epidermal cells may be important in connexion with the closing of the groove, for the greater the distance between the outer and inner walls the greater is the difference of curvature and the greater therefore will be the effect of the approximation of them. Moreover, the greater the height of the cells, the greater the leverage at the disposal of the cohesion tension drawing the lateral walls together.

\section{Other Anatomical Features.}

Raised Stomata. The stomata, as already described, are raised into

1 R. Marloth: Die Schutzmittel der Pflanzen gegen übermässige Insolation. Ber. d. D. Bot. Ges., xxvii, 1909, p. 362.

${ }^{2}$ F. J. Harris and H. S. Hoyt in Lniv. of California Publ. in Path., ii, I919, pp. 245-50; see Physiol. Abstr., iv, 1919, p. 203. Entry 1822 also i. p 686. Entry 2751 . 
the groove among the hairs (Fig. 3). The effect is to bring the pore slightly nearer the mouth of the groove and to provide a short tube within. In neither case can the effect on diffusion be important. When the leafgroove is narrowed, however, the inner epidermis is thrown into folds, and I incline to the view that the slightly raised position of the stomata prevents mechanical closure of the pores. It may also secure greater freedom of opening, as compared with stomata in which the guard cells have to push directly against adjacent cells supported by the rest of the epidermis, as well as reducing to a minimum any mutual interference of adjacent stomata.

Fibres. The fact that in $P$. filiformis the fibres interrupt the palisade layer outside the principal bundles has already been mentioned. The fibres extend farther, however, spreading laterally between the epidermis and

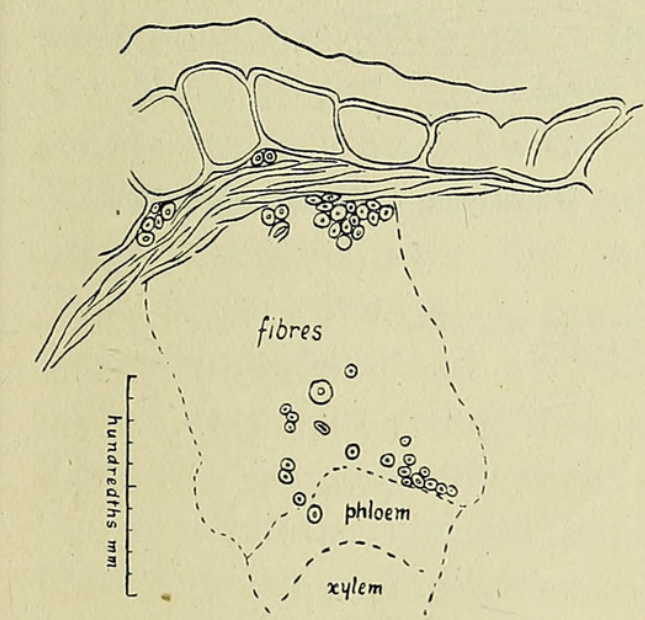

FIG. 6. Section through median bundle of leaf of $P$. filiformis, showing lateral wandering of fibres hypodermally. The fibres drawn near the phloem were the only ones that stained yellow with chlor-zinc-iodine.

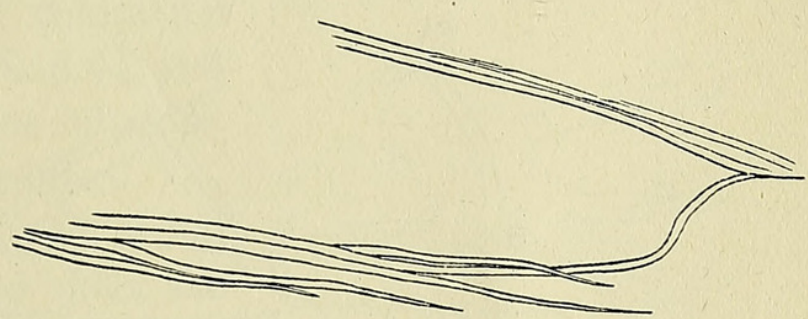

FIG. 7. Fibres of ordinary form from minor vein of young leaf of $P$. filiformis.

palisade tissue, where they are seen in transverse sections cut in various directions (Fig. 6). This feature is more strongly marked towards the tip, less strongly towards the base of the leaf.

The small size of the leaf and very small diameter of the fibres $\left(5^{-10 \mu)}\right.$ make it difficult to follow the wanderings of the fibres in sections. Boiling for a few minutes in Schulze's macerating solution makes it possible, however, to remove the epidermis from both sides, and preliminary observations have been made in this way.

In young leaves, associated with the minor veins, fibres of the usual type can be seen, slender and tapering to a point at both ends (Fig. 7). Near the tip in young leaves and extending towards the base in older leaves is found a sub-epidermal sheath of wandering fibres quite different in character. Their tips are often slightly swollen and club-shaped. Their growth is clearly apical. Evidence of similar growth is found deeper in 
the leaf associated with the bundles, as well as hypodermally between the bundles.

Figs. 8 and 9 illustrate these points. In Fig. 8 the irregular course

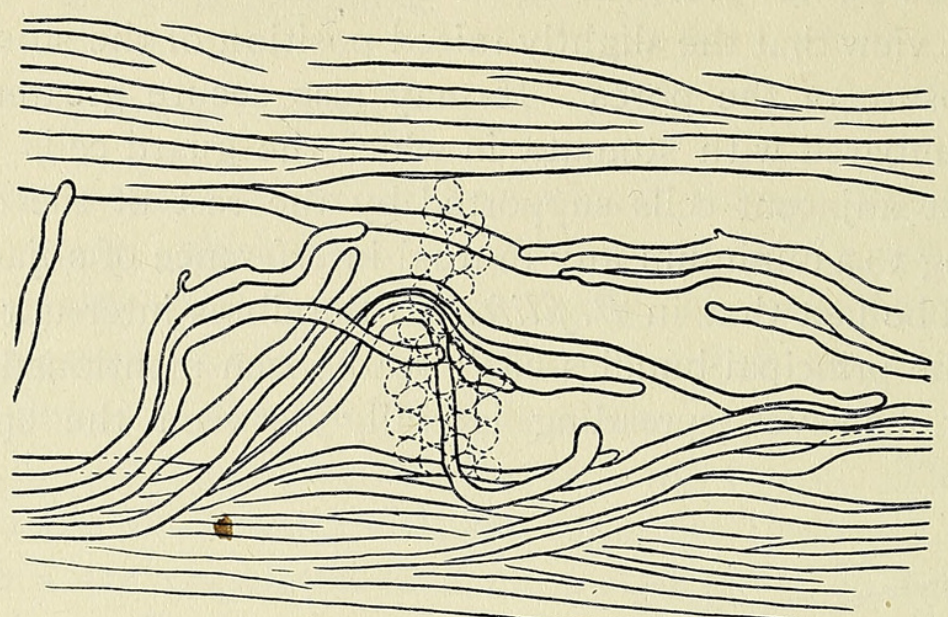

FIG. 8. Hypodermal wandering fibres between two veins. Underlying palisade cells dotted.
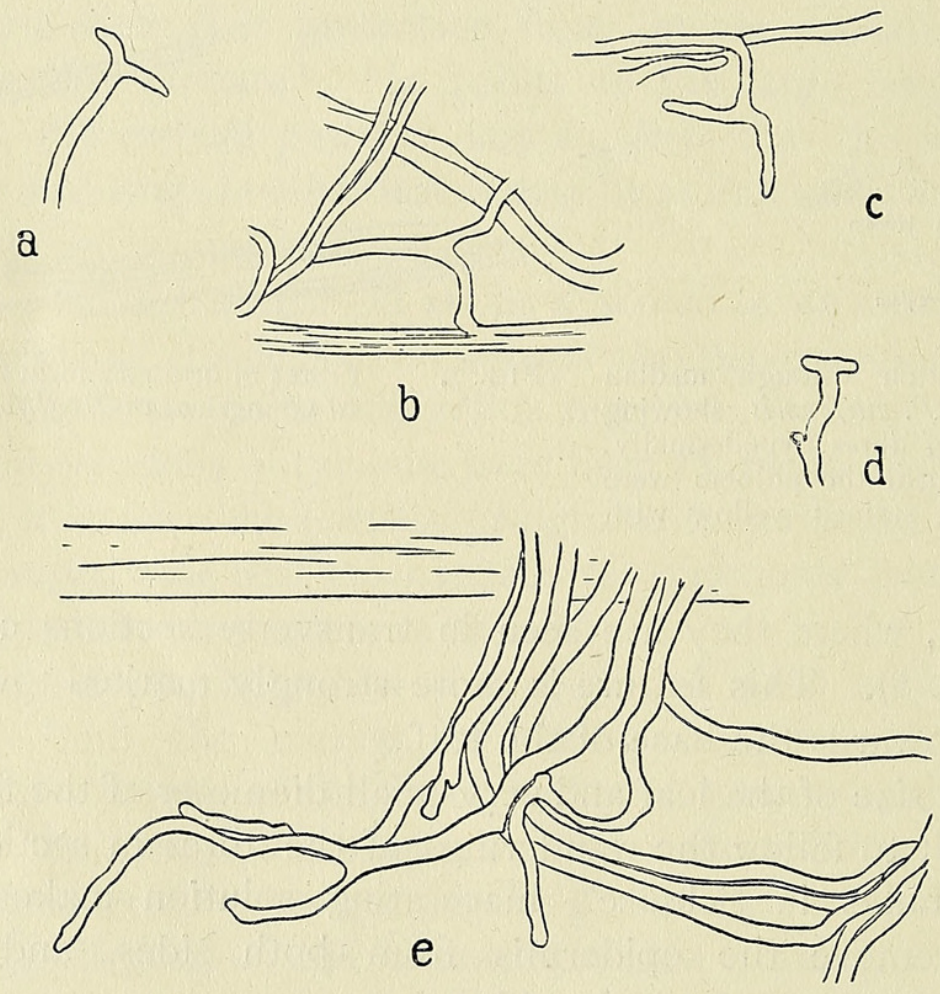

FIG. 9. $a-e$. Branching hypodermal fibres.

of the hypodermal fibres is shown, between the bundles from which they are wandering in different directions. Part of the palisade tissue is shown underlying these fibres.

It is probable that the fibres sometimes branch. Incipient branching is easy to observe (Fig. 9). Clear evidence of both arms continuing 
development is more difficult to obtain as the fibres soon become closely interwoven. The clearest case found is shown in Fig. $9, b$.

In $P$. cf. falcifolia fibres are not found except in association with the vascular bundles. Nevertheless, at the free endings of the finer veins, fibres are found with club-shaped tips, suggesting that they have spread by similar hyphal growth from the larger veins (Fig. IO).

The origin of these peculiar hyphae has not yet been observed, and their development requires further study. It seems not unlikely that hyphal growth begins at the leaf apex and that reinforcement of the strands of fibres in both species, as well as the formation of the hypodermal sheath in $P$. filiformis, is brought about in this way. All that can be definitely stated at present is that the hypodermal sheath is formed at a very early stage near the apex of the leaf.

Most of the fibres have cellulose walls stainly strongly purple with chlor-zinc-iodine. Relatively few are stained yellow, and these occur scattered near the phloem (Fig. 6). Even these give no appreciable coloration with phloroglucin and hydrochloric acid, and only a very faint yellow with aniline sulphate. They are therefore only slightly lignified.

It might be expected that the hypodermal fibrous sheath of $P$. filiformis would affect the closing mechanism, but I have not been able to obtain any evidence of this from a comparison with $P$. cf. falcifolia. Shoots of the latter collected in spring transpire at first more rapidly than those of $P$. filiformis, but this is probably due principally to the leaves spreading more widely, exposing the grooves.
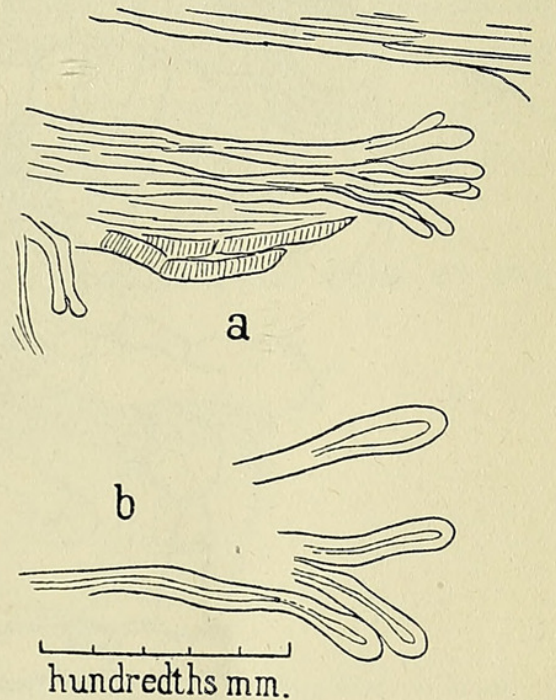

undredths $\mathrm{mm}$.

FIG. ro. a. Ultimate vein ending freely, from shade leaf of $P$. cf. falcifolia. The strand of fibres projects like a brush beyond the vascular tissue. The club-shaped tips are shown on a larger scale in $b$. In $a$ (left) two fibres show abortive wandering. The data already given, showing the close correlation between closure and water content in shoots collected without discriminating between the two species, indicate that the water content at which closure was complete was the same in both. The significance of the fibrous sheath is a problem, however, on which further evidence is required.

\section{Fuvenile Leaves.}

Seedlings and young plants have been found belonging to $P$. filiformis, the adult leaves having the palisade layer interrupted and the hypodermal sheath of wandering fibres. Immediately above the cotyledons for a variable distance the leaves are quite different in character (Figs. II and I2), being only slightly concave, glabrous, and more or less glaucous. The lower ones 
may show. interruption of the palisade layer by fibres, often only in the lateral veins, and extending for a variable distance from the tip. The fibres appear to be, at least the majority of them, of the ordinary tapering form. In leaves higher up, but still juvenile, lateral wandering of fibres from the strands associated with the vascular bundles is already found.

Stomata occur only on the concave upper side. They are not raised, but, on the contrary, are sunk below the surface of the epidermis, and flush with the inner walls (Fig. I2).

The majority of the epidermal cells have thick mucilaginous inner walls (Fig. II) which normally occupy a volume about equal to that of the
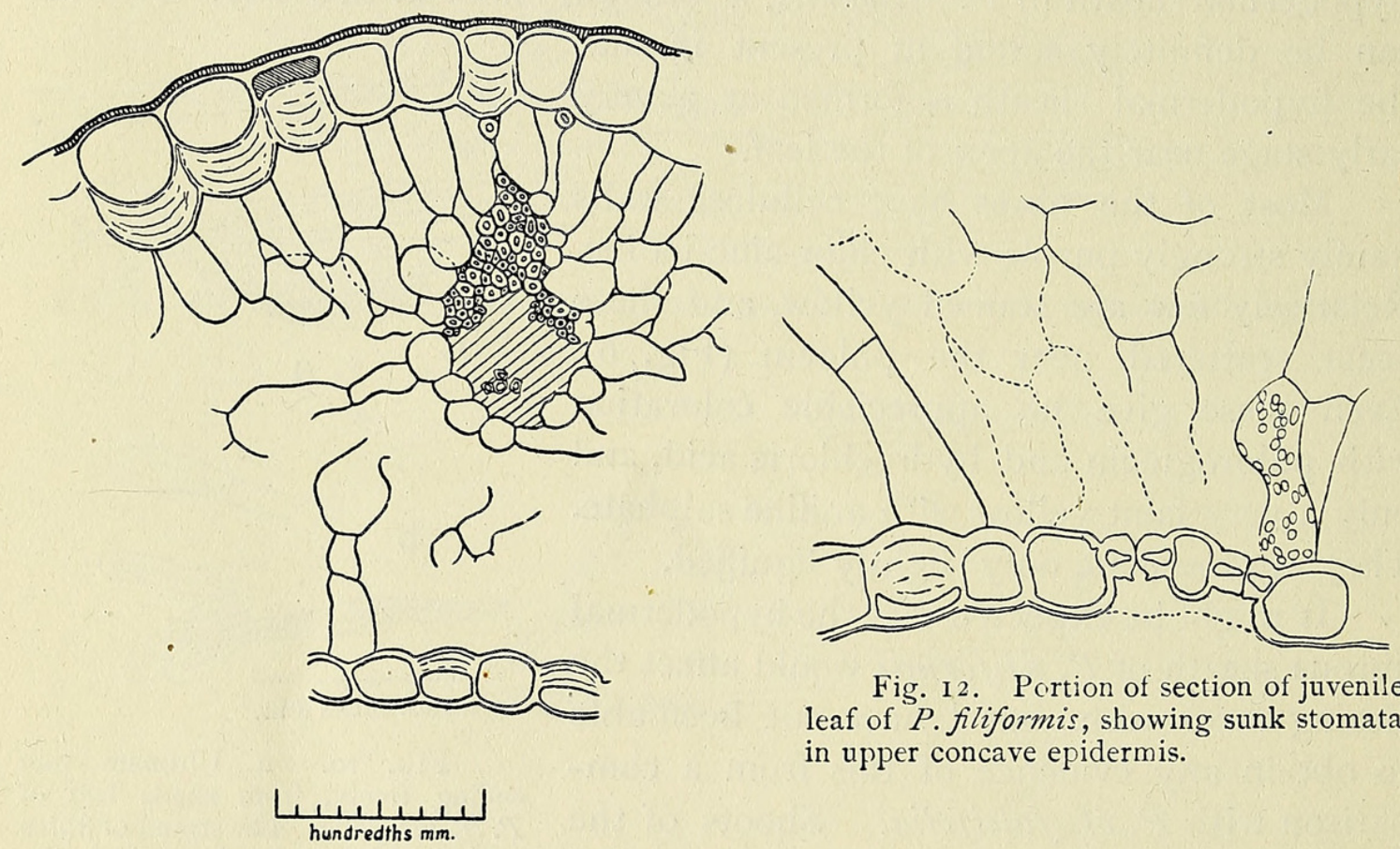

Fig. I 2. Portion of section of juvenile leaf of $P$. filiformis, showing sunk stomata in upper concave epidermis.

FIG. I r. Middle part of section of juvenile leaf of $P$. filiformis. Epidermis with mucilaginous inner walls; a few fibres wandering longitudinally from the bundle.

lumen. These cells are very similar in appearance to the epidermal cells of Evica spp. According to Supprian, ${ }^{1}$ mucilage is found in the epidermis of Passerina ericoides, Linn., but not in other species of the genus. It is found, however, in some species of most of the genera of Thymelaeaceae, including Anthrosolen and Chymococca, both closely allied to Passerina. Preliminary observations of my own point to a wider distribution of this character in Passerina than Supprian recorded, but definite statements are necessarily deferred until the species are satisfactorily identified.

In leaf form, absence of groove and woolly hairs, sunk stomata, and mucilaginous inner walls of the epidermal cells the juvenile leaves of $P$. filiformis approximate to those of many other members of the Thyme-

1 Beiträge zur Kenntnis der Thymelaeaceae. Engler's Bot. Jahrb., xviii, I894, p. 310. 
laeaceae. They represent, therefore, in all probability, a more generalized ancestral type, the ericoid adult leaf being highly specialized.

The transition from juvenile to adult leaves is often remarkably sharp, at one node typical juvenile leaves being borne, at the next typical adult leaves. Occasionally, however, transitional forms are found, with a few woolly hairs towards the tip, which is more involute than in the normal juvenile leaf. But in such cases the stomata, so far as I have observed, are still of the sunk type. The transition is, on the other hand, more often gradual in respect of mucilage. The first adult leaves have a number of epidermal cells on the outer flanks with thick mucilaginous inner walls, and cells may be found here and there in leaves much higher on the young plant which still show the same feature. The transition is also gradual in the degree of development of fibres. The upper juvenile leaves show the characteristic hypodermal sheath of fibres spreading laterally from the veins, and the palisade layer is interrupted at the midrib as well as at the two chief lateral veins.

In reference to the gelatinous contents of the epidermal cells of the

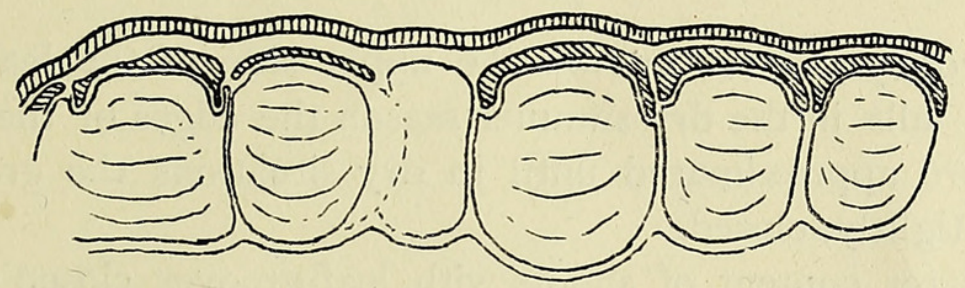

FIG. I 3. Dead cells from epidermis of juvenile leaf, showing swelling of mucilage and collapse of lumen. Cuticle and brown contents shaded.

adult leaf, it has been suggested that one advantage lies in the hindrance offered to complete collapse of the cells, if, as sometimes happens in the older leaves, they die prematurely. The mucilage in the epidermis of older juvenile leaves has still more conspicuously a similar action. In dead cells the mucilage swells till it occupies nearly the whole volume of the cell and compresses the lumen with its brown contents into a very small space at the top of the cell (Fig. I3).

Fuvenile leaves in P. cf. falcifolia. Seedlings of this form I have seldom found. The lower juvenile leaves are very similar to those of $P$. filiformis, but agree with the adult leaves of the species in having a continuous palisade tissue. Fibres are in fact feebly developed. The number of examples seen is too few for safe generalization, but the mesophyll suggests a shade leaf, with the palisade tissue less strongly developed and the spongy tissue more lacunar than in $P$. filiformis. Other observations of a preliminary nature on the distribution of the two species also point to $P$. cf. falcifolia being a species relatively tolerant of shade, whereas $P$. filiformis grows best in the open, fully exposed to the sun 
On a recently burned slope I have found juvenile shoots of $P . c f$. falcifolia growing from the bases of old charred stems. These, while similar in structure to the juvenile leaves of the seedling, often reached a much larger size, sometimes $2 \mathrm{~mm}$. or more in width, whereas the seedling leaves do not exceed I mm.

As in $P$. filiformis, the transition to the adult form is abrupt in respect of grooves, hairs, and stomatal structure.

Cotyledons. The expanded cotyledons of $P$. filiformis have yet another type of structure. Unlike the juvenile and adult leaves, they are convex above, and the palisade tissue, which is feebly developed, is on the upper, not the under side. The stomata, on the other hand, as in the other types, are confined to the upper side of the cotyledons; but they are neither raised nor sunk. Cells with mucilaginous inner walls are found in both the upper and the lower epidermis.

\section{SUMMARY.}

The structure and behaviour in drought of the ericoid leaves of two Cape species of Passerina, P. filiformis, Linn., and P.cf. falcifolia, C. H. Wright, are described.

I. The woolly grooves are on the upper side of the leaves. As the water content falls in the dry summer season the edges of the leaf become more and more approximated until in dry situations the groove is completely, even tightly, closed.

2. The water content of shoots with leaf-grooves closed ranged, early in March, I920, i.e. in the latter part of a very dry summer, from 34 per cent. down to as low as 25.7 per cent. The water content of fully turgid shoots at this time was only 47 per cent. At the end of the winter rainy season (October) the water content of shoots with new growth was about 60 per cent.

3. Evidence is adduced for attributing closure to cohesion forces developed in the outer epidermis, the cells of which are large and deep, and are provided with a very thick cuticle. As they contract with loss of water their lateral walls are thrown into bellows-like folds.

4. The mesophyll, however, contracts in volume during closure at least as much as the epidermis, and the palisade tissue may show fine bellowslike foldings of the walls. Reasons are given for regarding water storage as at most a subsidiary function, of little importance in prolonged drought, and other advantages of a deep-celled epidermis are considered, especially in relation to the closing mechanism and screening from intense insolation.

5. Anatomically, the leaves of the two species agree in most points, including stomata raised in the groove. They differ in the degree of development of the fibres, which in $P$. filiformis interrupt the palisade tissue 
Cape Species of Passerina, with some Notes on their Anatomy. 60 I

outside the chief bundles and spread laterally under the outer epidermis. In surface view, in macerated preparations, the hypodermal fibres are seen wandering like hyphae between the bundles, taking an irregular course, growing apically and occasionally branching. Indications of similar apical growth were found also in the other species, where there is, however, no hypodermal sheath of wandering fibres and the palisade is continuous.

6. The seedlings of both species have juvenile leaves which are slightly concave but not grooved, and are glabrous, with a waxy bloom. The stomata are not raised but sunk, and most of the epidermal cells have thick mucilaginous inner walls, as in adult leaves of species of most genera of the Thymelaeaceae.

7. The cotyledons of $P$. filiformis are convex above, have palisade tissue on the upper side, not as in the juvenile and adult leaves on the under side, and the stomata, though confined to the upper side, are neither raised nor sunk. 


\section{$2 \mathrm{BHL}$ Biodiversity Heritage Library}

Thoday, David. 1921. "On the behaviour during drought of leaves of two Cape species of Passerina, with some notes on their anatomy." Annals of botany 35, 585-601. https://doi.org/10.1093/oxfordjournals.aob.a089778.

View This Item Online: https://www.biodiversitylibrary.org/item/235780

DOI: https://doi.org/10.1093/oxfordjournals.aob.a089778

Permalink: https://www.biodiversitylibrary.org/partpdf/319021

\section{Holding Institution}

Smithsonian Libraries

\section{Sponsored by}

Biodiversity Heritage Library

\section{Copyright \& Reuse}

Copyright Status: Not in copyright. The BHL knows of no copyright restrictions on this item.

This document was created from content at the Biodiversity Heritage Library, the world's largest open access digital library for biodiversity literature and archives. Visit BHL at https://www.biodiversitylibrary.org. 